UDK 355.425(4-672EU)

Biblid 0543-3657, 72 (2021)

God. LXXII, br. 1181, str. 23-50

Pregledni rad

Primljen: 21.10.2020.

Prihvaćen 27.1.2021.

doi: https://doi.org/10.18485/iipe_mp.2021.72.1181.2

Slađana ĆURČÍ́

\title{
Suprotstavljanje hibridnim pretnjama u bezbednosnoj politici Evropske unije
}

\section{SAŽETAK}

Cilj rada je prikaz tematizacije hibridnih pretnji u bezbednosnoj politici Evropske unije i način na koji im se Unija suprotstavlja na praktičnopolitičkom planu. $\mathrm{Na}$ osnovu kvalitativne analize sadržaja strateških dokumenata, kao metodološkog pristupa i analize političkog i institucionalnog okvira u ovoj oblasti, konstatuje se da je EU u svojoj bezbednosnoj politici u značajnoj meri orijentisana na hibridne pretnje, ali da opravdano vođenje takve politike zahteva više koherentnosti i preciznosti u objašnjenju i operacionalizaciji hibridnih pretnji, s obzirom na njihovu nejasnu i kompleksnu prirodu. Drugim rečima, zaključuje se da se postepeni prelazak na multipolarni svetski poredak, skopčan sa istovremenim jačanjem tehnološke dimenzije savremenih sukoba, te suočavanjem Unije sa spletom kriza, novih neizvesnosti i preispitivanjem sopstvenog „identiteta“ i uloge na globalnoj geopolitičkoj sceni, može tumačiti kao kontekst koji je generisao "sliku složenosti i hibridnosti“, te i evropsku percepciju bezbednosnih pretnji kao hibridnih.

Ključne reči: Evropska unija, hibridne pretnje, hibridni rat, bezbednosna politika, savremeni sukobi, bezbednosno okruženje.

\section{Uvod}

Složenost i neizvesnost globalnog bezbednosnog okruženja, koji su na početku XXI veka doneli niz novih pretnji i izazova, posledično su se

\footnotetext{
${ }^{1}$ Autorka je doktorantkinja na Fakultetu bezbednosti Univerziteta u Beogradu. E-mail: scurcic50@gmail.com
} 
reflektovali i na ravan teorijskog, inicirajući opsežne debate, promišljanja, ali i nove koncepte i pojmove, kao pokušaj razumevanja i objašnjenja izmenjene bezbednosne realnosti. Tako su rasprave o hibridnom ratu/hibridnim pretnjama, postale dominantne i sveprisutne $u$ akademskom, političkom $i$ medijskom diskursu, a prevashodno $u$,zapadnim“ vojnim i bezbednosnim krugovima, odražavajući zapravo „nove-stare“ dileme o transformaciji rata, odnosno karakteru savremenih sukoba. Frenk Hofman (Frank Hoffman), kao teoretičar koji se smatra začetnikom koncepta hibridnog ratovanja i koji je dao najveći doprinos teorijskim razmatranjima i istraživanjima ove problematike, tezu o hibridnom ratu kao dominantnoj formi modernog ratovanja zasniva na činjenici o složenosti i neizvesnosti savremenog sveta, te i pretnji, promena i procesa u sferi bezbednosti, koji nam ne dozvoljavaju pojednostavljeno klasfikovanje konflikata na „velike i konvencionalne“ i "male i iregularne", te otuda zamagljivanje ovih granica vodi fuziji različitih formi ratovanja oličenih u terminu ,"hibridno ratovanje“. ${ }^{2}$ Naime, očigledno je da su sažimanje i međusobna uslovljenost tehnoloških, geopolitičkih, socioloških, bezbednosnih i ekonomskih procesa i promena, oličeni upravo $\mathrm{u}$,hibridnosti“, odnosno hibridnim pretnjama, kao kompleksnom i čini se, apstraktnom pojmu. Drugim rečima, transformaciju savremenih sukoba, te i ekspanziju hibridnih pretnji, potrebno je sagledavati $u$ širem okviru političko-ekonomskih kretanja i bezbednosnih procesa, koje čine: okončanje Hladnog rata i postepeni prelazak na multipolarni svetski poredak (uspon Kine, Rusije, Indije, sve značajnija uloga Turske, uz relativno slabljenje moći SAD i istovremenu krizu EU, ali i krizu transatlantskih odnosa), napredovanje procesa globalizacije i informatizacije (ubrzan razvoj modernih tehnologija, digitalizacija društvenog života i umreženost ljudi, pojava i procesa, usavršavanje oružja, koje potom menja karakter konflikata i način ratovanja), transnacionalizacija pitanja bezbednosti i sve značajnija uloga nedržavnih aktera na globalnom nivou. Tako se jedno od ishodišta izmenjenih bezbednosnih okolnosti ogleda $u$ apostrofiranju hibridnih pretnji u bezbednosnoj politici EU u poslednjih nekoliko godina, prevashodno kroz njihovu zastupljenost $\mathrm{u}$ brojnim strateškim dokumentima, operacionalizaciju kroz određene politike i prakse i prateću institucionalnu strukturu za suprotstavljanje istim. Stoga, imajući u vidu sui generis karakter EU, u pogledu njenog ustrojstva, prirode moći, uloge i političko-bezbednosnog identiteta, te uticaja na globalnoj sceni, razmatranje i razumevanje pretnji koje ona identifikuje kao značajne po svoju bezbednost, ima praktičnopolitički, ali i naučnoistraživački značaj. Kako je spoljnopolitička retorika ključnih globalnih aktera, često oblikovana narativom o hibridnim pretnjama, koje dolaze od one druge strane (uslovno rečeno - „zapadna“ i ",istočna“" perspektiva hibridnog ratovanja), to se nužno odražava na njihove

${ }^{2}$ Frank G. Hoffman, Conflict in the 21st Century - The Rise of Hybrid Wars, Potomac Institute for Policy Studies, Arlington, Virginia, 2007, p. 57. 
međusobne odnose, te i na međunarodni poredak u celini. Sa druge strane, sama činjenica da je reč o spornom i relativno novom konceptu i nedovoljno istraženoj oblasti, jeste ono što suštinski inicira potrebu za daljim istraživanjem, traganjem za novim saznanjima, ne bi li se obogatio naučnoistraživački korpus navedene oblasti.

\section{Teorijska određenja hibridnih pretnji $i$ sličnih pojmova}

$S$ obzirom na to da je sam pojam "hibridnih pretnji“ politički kontroverzan, te da ne postoji opšta saglasnost $u$ pogledu njegovog značenja, analitičke i praktične vrednosti i da se stoga često poistovećuje sa sličnim, a podjednako spornim pojmovima "hibridni rat" / "hibridno ratovanje“, u ovom delu fokus je na pregledu postojećih određenja hibridnih pretnji i srodnih pojmova, kroz definicije pojedinih teoretičara i zvanične pristupe uticajnih globalnih činilaca -SAD, NATO i Ruske Federacije. Istaknutu ulogu u tematizaciji hibridnih pretnji i hibridnog ratovanja, na početku XXI veka imali su teoretičari koji pripadaju „zapadnim“ vojnim krugovima (Robert Walker, Margaret S. Bond, Glenn W. Russell, James Mattis), pri čemu je pomenuti Frenk Hofman dao najveći doprinos konceptualizaciji hibridnog ratovanja, oslanjajući se na saznanja o sukobima u Avganistanu, Iraku i Libanu. ${ }^{3}$ Naime, on navodi da hibridne pretnje obuhvataju ,širok spektar različitih modela sukobljavanja, uključujući konvencionalne kapacitete, iregularne taktike i formacije, terorističke akte, nasumično nasilje i prinudu, organizovane kriminalne akte i nerede, pobune, gerilski način ratovanja, kao i sajber napade i napredne vojne tehnologije“. ${ }^{4}$ Hofman dodaje da "hibridno" obuhvata kako organizaciju tako i sredstva koja će protivnici koristiti, te da hibridne pretnje mogu dolaziti kako od države, tako i nedržavnih činilaca, ali su generalno, ove aktivnosti operativno ili taktički usmerene $\mathrm{i}$ koordinirane kako bi se postigli sinergetski efekti u fizičkoj i psihološkoj dimenziji konflikta. ${ }^{5}$ Stojković definiše hibridne pretnje kao „potencijalne, složene, multidimenzionalne opasnosti nastale istovremenim delovanjem državnih i/ili nedržavnih subjekata koji na adaptivan način kombinuju konvencionalna i nekonvencionalna sredstva radi ostvarenja zajedničkih ciljeva". ${ }^{6}$ Iako su u literaturi prisutna i mišljenja da je ispravnije govoriti o hibridnom ratovanju (hybrid warfare), kao održivom i koordinisanom konfliktu između različitih i suprotstavljenih političkih organizacija, a ne

\footnotetext{
${ }^{3}$ Milinko S. Vračar i Vladlena V. Tikhova, „Diskurzivni pristup fenomenu hibridnog ratovanja", Vojno delo, vol. 70, br. 3, 2018, str. 317-342.

${ }^{4}$ Frank G. Hoffman, Conflict in the 21st Century - The Rise of Hybrid Wars, op. cit., p. 8.

${ }^{5}$ Ibid.

${ }^{6}$ Dejan Stojković, „Hibridne pretnje bezbednosti Republike Srbije“, Vojno delo, vol. 69, br. 6, 2017, str. 284 .
} 
hibridnom ratu, s obzirom na to da hibridni rat može da ima početak, ali zbog prirode aktera i njihovog političkog ponašanja u sukobu teško je odrediti trenutak pobede koji bi istovremeno značio okončanje konflikta, ${ }^{7}$ očigledno je pak da se u razmatranju karaktera savremenih sukoba, koriste sva tri pojma - hibridne pretnje/hibridni rat/hibridno ratovanje, uz manje ili više istaknute razlike. Tako Njuson (Robert A. Newson), određuje hibridni rat kao „kombinaciju konvencionalnih, iregularnih i asimetričnih sredstava, odnosno kombinaciju specijalnih operacija i konvencionalnih vojnih snaga, ekonomskog zastrašivanja, sajber napada i kriminalnih elemenata, kao i delovanje proksija i surogata, obaveštajnih agenata, političkih aktera, predstavnika medija, paravojski i terorista". ${ }^{.}$

U četvorogodišnjem pregledu odbrane SAD (Quadrennial Defense Review) iz 2010. godine, navodi se da se termin "hibridni“ odnosi na "povećanu složenost rata, brojnost i raznolikost učesnika, te na zamagljivanje tradicionalnih kategorija sukoba" ${ }^{9}$ Iako se u najnovijim strategijama u oblasti bezbednosti i odbrane SAD - Strategiji nacionalne bezbednosti (2017), Nacionalnoj strategiji odbrane (2018) i Nacionalnoj vojnoj strategiji (2018), ne navode eksplicitno termini hibridne pretnje/hibridni rat, mada se u prve dve posredno može uočiti pristup zasnovan na konceptu hibridnog ratovanja, u Vojnoj strategiji SAD iz 2015. godine, hibridni konflikt je definisan kao „područje preklapanja državnog i nedržavnog nasilja, gde akteri kombinuju svoje tehnike, sposobnosti i resurse za postizanje svojih ciljeva". ${ }^{10}$ Navodi se da hibridni sukobi zamagljuju granice, otežavaju donošenje odluka i usporavaju koordinaciju efikasnog odgovora, budući da mogu uključivati i državne i nedržavne aktere koji zajedno rade na ostvarenju ciljeva, koristeći širok spektar metoda, kakav je slučaj bio u istočnoj Ukrajini, te se procenjuje da će zbog takvih prednosti agresora, ovaj oblik sukoba i dalje postojati u budućnosti. ${ }^{11}$ To potvrđuje i činjenica da se na zvaničnoj internet stranici Ministarstva odbrane SAD, navodi da je hibridno ratovanje realnost i da američka vojska mora biti spremna da se

\footnotetext{
${ }^{7}$ Igor Pejić, „,Ruske vojne hibridne operacije u Ukrajini: prilagođavanje strategije i taktike savremenoj strukturi rata", Međunarodni problemi, vol. 71, br. 4, 2019, str. 423-446.

${ }^{8}$ Robert A. Newson, Counter-Unconventional Warfare Is the Way of the Future. How Can We Get There?, Small Wars Journal, 23 October 2014, Internet, https://smallwars journal.com/blog/counter-unconventional-warfare-is-the-way-of-the-future-how-canwe-get-there, 04/09/2020, p. 10.

9 "Quadrennial Defense Review", U.S. Department of Defense, Washington D.C., March 2010, Internet, https://archive.defense.gov/qdr/QDR\%20as\%20of\%2029JAN10\% 201600.pdf, 04/09/2020, p. 8.

10 "The National Military Strategy of the USA", Department of Defense, Washington D.C., June 2015, Internet, https:// www.jcs.mil/Portals/36/Documents/Publications /2015_National_Military_Strategy.pdf, 04/09/2020,p. 4.
}

$26{ }^{11}$ Ibid. 
tome suprotstavi i odvrati pretnje, koje mogu uključivati „informacione operacije, razmeštanje trupa, propagandne kampanje, sajber napade ili kombinaciju svega navedenog", odnosno, kako se ističe, "to je amorfna definicija za amorfnu strategiju“. ${ }^{12}$

Kao deo „zapadnog modela" hibridnog ratovanja, nužno je istaći i pristup NATO saveza, budući da je aktuelnost ovog koncepta na nivou Alijanse naročito intenzivirana nakon krize $u$ istočnoj Ukrajini, te su politički i strateški pristup NATO ovom fenomenu, kao i „zapadna“ akademska i istraživačka literatura, u velikoj meri oblikovani narativom o "ruskoj hibridnoj pretnji“ NATO pod hibridnim pretnjama podrazumeva "kombinaciju vojnih i nevojnih sredstava, kao i prikrivenih i regularnih metoda, uključujući dezinformisanje, sajber napade, ekonomske pritiske, raspoređivanje neregularnih oružanih grupa, ali i upotrebu redovnih snaga. " ${ }^{13}$ Naglašava se da su se obim i intenzitet hibridnih pretnji povecali poslednjih godina, te je spremnost da spreči, suprotstavi se i odgovori na hibridne napade, bilo državnih ili nedržavnih aktera, glavni prioritet Alijanse. ${ }^{14}$ Naime, sam koncept hibridnog ratovanja je postepeno "evoluirao" u političkom i institucionalnom okviru NATO, dobijajući sve više na značaju, počev od novog Strateškog koncepta za 2010. godinu, preko usvajanja Akcionog plana pripravnosti na samitu u Velsu (2014), ${ }_{15}^{15}$ Strategije suprotstavljanja hibridnim pretnjama na samitu u Varšavi (2016), ${ }^{16}$ da bi se dve godine kasnije, u Deklaraciji Alijanse sa samita u Briselu, istakla ozbiljnost hibridnih izazova, koji uključuju „kampanje dezinformisanja, sajber napade i hibridne aktivnosti državnih i nedržavnih aktera, koji imaju za cilj stvaranje nejasnoća i zamagljivanje granica između mira, krize i sukoba." ${ }^{17} \mathrm{U}$ tom kontekstu, naglašavaju se „ruske agresivne akcije, koje pretnjom i upotrebom sile za postizanje političkih

${ }^{12}$ U.S. Department of Defense, Military Must Be Ready to Confront Hybrid Threats, September 2019, Internet, https://www.defense.gov/Explore/Features/story/ Article/1952023/military-must-be-ready-to-confront-hybrid-threats-intelligenceofficial-says/source/GovDelivery/, 07/10/2020.

${ }^{13}$ North Atlantic Treaty Organization, NATO's response to hybrid threats, August 2019, Internet, https://www.nato.int/cps/en/natohq/topics_156338.htm, 07/09/2020.

${ }^{14}$ Ibid.

15 "Wales Summit Declaration”, North Atlantic Council, Wales, 5 September 2014, Internet, https:/ / www.europarl.europa.eu/meetdocs/2014_2019/documents/sede/ dv/sede240914walessummit_/sede240914walessummit_en.pdf, 07/09/2020, p. 1.

16 "Warsaw Summit Declaration", para. 37, North Atlantic Council, Warsaw, 8-9 July 2016, Internet, https://www.nato.int/cps/en/natohq/official_texts_133169.htm, 07/09/2020.

17 "Brussels Summit Declaration", North Atlantic Council, Brussels, 11-12 July 2018, Internet, https://www.nato.int/nato_static_fl2014/assets/pdf/pdf_2018_07/201807 13_180711-summit-declaration-eng.pdf, 07/09/2020, p. 8. 
ciljeva, izazivaju Alijansu i podrivaju evroatlantsku bezbednost i međunarodni poredak zasnovan na pravilima. "18

Dok se u „zapadnoj sferi“, Rusija vidi kao glavni izvor hibridnih pretnji, u Strategiji nacionalne bezbednosti i Vojnoj doktrini Ruske Federacije, ne govori se o hibridnim pretnjama/hibridnom ratu, iako se na izvestan način obrazlažu promene u načinu ratovanja. ${ }^{19}$ Sa druge strane, razmatranje ovih fenomena/koncepata je prisutno $\mathrm{u}$ akademskoj i stručnoj literaturi, te tako Vladimirov (Владимиров) hibridni rat definiše kao „modernu verziju rata koja se ispoljava kao sukob nedržavnih naoružanih grupa sa državom ili kao invazija na drugu državu bez zvaničnog učešća legalnih oružanih snaga države", ${ }^{20}$ dok Stoljetov (Сmолеmoß) navodi da hibridne ratove vodi svojevrsni "simbiotski subjekat", što podrazumeva združeno delovanje država, nedržavnih aktera (npr. transnacionalnih terorističkih organizacija ili ekstremističkih pokreta) i unutardržavnih aktera (oligarhijskih grupa ili pseudoreligijskih organizacija). ${ }^{21}$ Iako se u zapadnim vojnim krugovima, shvatanje ruskog načelnika generalštaba Valerija Gerasimova (Вале́puũ Гера́симов) o mnogobrojnim promenama $u$ savremenoj strukturi međunarodnih odnosa, koje se ujedno reflektuju na mogućnosti i način primene vojne sile u XXI veku, tumači kao „ruska doktrina hibridnog rata“ , ${ }^{22}$ Rusi je jednostavno označavaju kao "nova vojna doktrina Ruske Federacije." ${ }^{23}$ Dakle, dok se s jedne strane navodi da u ruskoj stručnoj literaturi postoje brojne kritike koncepta hibridnog ratovanja i hibridnih pretnji $^{24} \mathrm{i}$ da se rusko viđenje nove generacije ratova ne može podvesti pod koncept hibridnih ratova, onako kako ga zapadni analitičari definišu, ${ }^{25}$

${ }^{18}$ Ibid., p. 1.

19 "Military Doctrine of the Russian Federation", Ministry of Defense, Moscow, 2014, Internet, https://www.offiziere.ch/wp-content/uploads-001/2015/08/Russia-s-2014Military-Doctrine.pdf, 07/09/2020, p. 4.

${ }^{20}$ Александр Владимиров, Гибридные войны в Общей теории войны, Военный университет МО РФ, Москва, 2015, стр. 12.

${ }^{21}$ Nebojša Vuković, „Prilog pojmovnom određenju sintagme hibridni rat", u: Nebojša Nikolić (ur.), Hibridno ratovanje - dilema koncepta savremenih sukoba, Institut za strategijska istraživanja, Beograd, 2018, str. 24.

${ }^{22}$ Igor Pejić, „Ruske vojne hibridne operacije u Ukrajini: prilagođavanje strategije i taktike savremenoj strukturi rata", op. cit., p. 427.

${ }^{23}$ Radomir Aleksandrić, „Istorijsko-komparativna analiza nastanka i eksploatacije doktrine hibridnog ratovanja u oružanim snagama Ruske Federacije“, u: Nebojša Nikolić (ur.), Hibridno ratovanje - dilema koncepta savremenih sukoba, Institut za strategijska istraživanja, Beograd, 2018, str. 125.

${ }^{24}$ Dejan Stojković, „Hibridne pretnje bezbednosti Republike Srbije“, op. cit., str. 283.

${ }^{25}$ Jānis Bērziņš, "Not 'Hybrid' but New Generation Warfare”, in: Glen E. Howard \& Matthew Czekaj (eds), Russia's military strategy and doctrine, The Jamestown

28 foundation,Washington D.C., 2019, pp. 157-184. 
očigledno je da su "zapadna“ i „istočna“ perspektiva hibridnih pretnji/hibridnih ratova gotovo identične, te da navodno pojmovno neslaganje zapravo proizilazi iz činjenice da njihovi protagonisti vide jedni druge kao izvor takvih pretnji. Naredni redovi će, kroz prizmu evropskog pristupa hibridnim pretnjama, osvetliti odnos EU i drugih globalnih sila u ovom kontekstu.

\section{Hibridne pretnje u političko-bezbednosnom kontekstu Evropske unije}

Razvoj zabrinutosti od hibridnih pretnji, zahvatio je EU u turbulentnom periodu višestruke i dugotrajne krize, koja se sažima u suštinskom problemu (re)definisanja političkog i bezbednosnog identiteta Unije. Poseban podsticaj za inkorporiranje hibridnih pretnji u spektar bezbednosnih problema sa kojima se EU suočava, predstavljala je kriza u istočnoj Ukrajini i ruska aneksija Krima. Razumevanje naglašavanja ove vrste ugroženosti, možda treba tražiti $\mathrm{u}$ često isticanoj tezi, da dejstva Rusije u ukrajinskoj krizi predstavljaju prekretnicu u razumevanju koncepta hibridnog ratovanja, upravo zbog toga što je iza tih aktivnosti stajala velika sila, država, a ne nedržavni akteri, kao što je bio slučaj u sukobima u Somaliji, Libanu, Avganistanu, Iraku itd. ${ }^{26}$ Indikativno je, naravno, da su na Zapadu (SAD, NATO i EU), naročito događaji u Ukrajini aktuelizovali opasnost od hibridnih pretnji, dok je sam koncept hibridnog ratovanja razvijen mnogo ranije, upravo od strane SAD i NATO, kao analitički pogodan okvir da se objasni sopstveni neuspeh $\mathrm{u}$ odnosu na komparativno znatno slabijeg protivnika, kao što su Talibani ili Al Kaida u ratovima u Iraku i Avganistanu, pri čemu i sami već nekoliko decenija primenjuju ovakav „model“ ratovanja, u okviru kojeg upotrebljavaju sva raspoloživa vojna i nevojna sredstva radi ostvarenja postavljenih ciljeva. ${ }^{27}$ Stoga su prisutne ocene da se problemi NATO i EU u suočavanju sa hibridnim pretnjama, šire i izvan ukrajinskog sukoba, te da su rezultat hroničnih nedostataka u evropskoj bezbednosnoj politici, prisutnih od 90-ih godina, odnosno da je u osnovi reč o sistematskoj ranjivosti zapadnih društava. ${ }^{28}$ Drugim rečima, to ostavlja utisak da se kroz retoriku o hibridnim pretnjama, odvija očigledna borba za novo geopolitičko pozicioniranje $\mathrm{u}$ procesu preoblikovanja svetskog poretka iz unipolarnog $\mathrm{u}$ multipolarni, gde EU nastoji da pronađe svoje mesto, SAD (preko NATO)

${ }^{26}$ Milinko Vračar, „Razmatranje adekvatnog teorijsko-epistemološkog pristupa u istraživanju fenomena hibridnog ratovanja“, Vojno delo, vol. 69, br. 7, str. 292-307.

${ }^{27}$ Davor Milošević, „Percepcija savremenih oružanih sukoba kao indikatora hibridnog koncepta rata, modeli prevencije i suprotstavljanja hibridnim pretnjama“", Vojno delo, vol. 70, br. 5, 2018, str. 272-293.

${ }^{28}$ Christian Mölling, "From Hybrid Threats to Hybrid Security Policy", Ethics and Armed Forces, vol. 2, no. 2, 2015, pp. 17/19. 
da održe dosadašnju poziciju, a Rusija da učvrsti „veliki povratak”, koji je demonstrirala upravo tokom ukrajinske krize i zauzimanja Krima.

U publikaciji Službe Evropskog parlamenta za istraživanja, navodi se da je termin hibridna pretnja, „metafora kojom se žele istaći složenosti i dileme povezane sa promenljivim globalnim okruženjem“, preciznije, „pojava koja rezultira iz konvergencije i međupovezanosti različitih elemenata, koji zajedno čine složeniju i višedimenzionalnu pretnju“ . ${ }^{29}$ Pri tome se, uzimajući u obzir različite nivoe intenziteta pretnje i namera uključenih aktera, pravi razlika između hibridnog sukoba i hibridnog rata. Hibridni sukob se definiše kao „situacija u kojoj se strane suzdržavaju od otvorene upotrebe oružane sile jedna protiv druge, oslanjajući se, umesto na kombinaciju vojnog zastrašivanja, na eksploataciju ekonomskih i političkih ranjivosti i diplomatskih ili tehnoloških sredstava za ostvarivanje svojih ciljeva“. ${ }^{30}$ Hibridni rat je „situacija u kojoj država pribegava otvorenoj upotrebi oružanih snaga protiv druge države ili nedržavnog aktera, pored kombinacije drugih sredstava - ekonomskih, političkih i diplomatskih" ${ }^{31} \mathrm{U}$ navedenom dokumentu navodi se lista primera hibridnih pretnji koja, između ostalog, uključuje terorističke pretnje (Boko Haram, Al Kaida, ISIL/Dae'sh), sajber pretnje u vidu hakerskih napada, koji se pripisuju Rusiji i Kini, organizovani kriminal, kinesku politiku u Južnom kineskom moru, kombinovanu sa ekonomskim i vojnim pritiscima, političku zloupotrebu zavisnosti od oskudnih resursa, ruske specijalne operacije u Ukrajini itd. ${ }^{32}$ Dakle, sve veća pažnja se posvećuje i kineskoj doktrini (i praksi) tzv. "trostrukog rata" - psihološkog, propagandnog i pravnog. Iako je razrađena sa posebnim osvrtom na Tajvan i Južno i Istočno kinesko more, brojni stručnjaci smatraju da takva strategija nadahnjuje sve asertivnije ponašanje Pekinga na međunarodnoj sceni. ${ }^{33}$ Evropska unija ima tendenciju da posebno istakne potencijalne razorne efekte hibridnih pretnji na funkcionisanje jedinstvenog tržišta, a odnedavno i na funkcionalnost domaćih političkih procesa, pošto je utvrđeno da bi sofisticirane hibridne kampanje mogle uticati

${ }^{29}$ Patryk Pawlak, Understanding hybrid threats, Briefing, European Parliamentary Research Service, Brussels, June 2015, Internet, https://www.europarl.europa.eu/RegData/ etudes/ATAG/2015/564355/EPRS_ATA(2015)564355_EN.pdf, 11/09/2020, p. 1.

${ }^{30}$ Ibid

${ }^{31}$ Ibid.

${ }^{32}$ Ibid., p. 2.

${ }^{33}$ Daniel Fiott \& Roderick Parkes, Protecting Europe - The EU's response to hybrid threats, Chaillot Paper, No.151, European Union Institute for Security Studies (EUISS), Paris, April 2019, Internet, https:/ / www.researchgate.net/profile/Daniel_Fiott/publication /333104934_Protecting_Europe_the_EU's_response_to_hybrid_threats/links/5cdbcef 9299bf14d95988c67/Protecting-Europe-the-EUs-response-to-hybrid-threats.pdf, $24 / 01 / 2021$. 
na integritet, pa čak i na ishod demokratskih izbora u državama EU. ${ }^{34}$ Građanski rat u Siriji, koji je vremenom prerastao u sukob međunarodnog karaktera, usled sukobljenih geostrateških interesa, takođe se navodi kao primer sukoba, koji ima karakteristike "hibridnosti“: osnovne kategorije ratne veštine su vrlo fleksibilne i uzajamno konvertibilne -građanski rat lako postaje međudržavni i nakon kratkog vremena opet zadobija formu unutrašnjeg konflikta, borac se kamuflira u neborca, da bi pri novim povoljnim okolnostima ponovo postao borac, jedna lokacija može u relativno kratkom periodu više puta da bude i front i pozadina, civilna materijalnotehnička sredstva ponekad se lako konvertuju u vojna i kada posluže novoj svrsi, ponovo postaju civilna i obratno. ${ }^{35}$ Osim toga, prisutne su intenzivne medijske kampanje, vođenje posredničkih (proxy) ratova, korišćenje sajber prostora za propagandu i vrbovanje terorista, kao i upotreba robotizovanih borbenih sistema ${ }^{36}$ Ovaj primer pokazuje kako multipolarnost usložnjava međusobne odnose između, sada većeg broja centara globalne moći, pa je teško razlučiti ko su zaraćene strane, čiji i koji su sve interesi uključeni u sukob. U svakom slučaju, ovaj sukob predstavlja dugotrajnu krizu čiji se efekti, iako nije uključena direktno, ozbiljno reflektuju na stabilnost i budućnost EU.

Kao „hibridne“ i „ratne“ označavaju se i neprijateljske obaveštajne operacije koje je Moskva sprovela na Zapadu - poput pokušaja atentata na bivšeg ruskog agenta Sergeja Skripalja (Сергей Скрипаль) ili neuspelog hakerskog napada na sistem Organizacije za zabranu hemijskog oružja $(\mathrm{OPCW})$ i Svetske antidoping agencije (WADA). ${ }^{37}$ Očigledno, Rusija je percipirana kao značajan izazov i ozbiljan izvor pretnji, što potvrđuje i opsežna analiza na nivou EU, posvećena ruskoj „asertivnijoj“ bezbednosnoj politici, povećanoj vojnoj i diplomatskoj aktivnosti u Evropi, ${ }^{38}$ što u celini ostavlja utisak više o zabrinutosti EU zbog ruskog jačanja i ofanzivnije politike poslednjih godina, nego zbog potencijalnih ili stvarnih hibridnih pretnji.

Dok se naglašava da su ovi događaji značajno izmenili evropsko bezbednosno okruženje i pretnje sa kojima se EU suočava, pojedini autori

${ }^{34}$ Antonio Missiroli, From Hybrid Warfare to 'Cybrid' Campaigns: The New Normal?, Center for Security Studies, Zürich, September 2019, Internet, https://css.ethz.ch/en/ services/digital-library/articles/article.html/a59d89dd-1179-453b-ab02-ade9097cf646, 11/09/2020.

${ }^{35}$ Nebojša Vuković, „Prilog pojmovnom određenju sintagme hibridni rat" , op. cit., str. 21.

${ }^{36}$ Miroslav R. Terzić, Mića D. Miladinović i Sabahudin Coković, „Hibridno ratovanje konceptualna adaptacija“, Vojno delo, vol. 69, no. 5, 2017, str. 348-357.

${ }^{37}$ Antonio Missiroli, From Hybrid Warfare to 'Cybrid' Campaigns: The New Normal?, op. cit.

${ }^{38}$ Isabelle Facon, Russia's national security strategy and military doctrine and there implications for the EU, In-depth analysis, European Union, Directorate-General for External Policies, Brussels, January 2017, Internet, https:/ / www.europarl.europa.eu/RegData/etudes /IDAN/2017/578016/EXPO_IDA\%282017\%29578016_EN.pdf, 11/09/2020. 
upravo angažman Evropske unije u istočnoj Evropi, kroz program istočnog partnerstva, karakterišu kao hibridnu ili liberalno-redukcionističku geopolitiku. ${ }^{39}$ Naime, rusko-ukrajinska kriza doprinela je da se EU transformiše u drugačijeg spoljnopolitičkog aktera, sa manjim naglaskom na promovisanju normi i pravila EU (tzv. meka moć), a većim fokusom na potencijalni geopolitički uticaj, kombinujući ofanzivne i defanzivne taktike, koristeći svoje karakteristične alate usmerene na produbljivanje saradnje i učvršćivanje bezbednosnih interesa sa državama istočnog susedstva. ${ }^{40}$ Sve navedeno govori da su hibridne pretnje za vodeće svetske sile realna opasnost, ali različito doživljena i viđena, tj. način definisanja i pristup ovom fenomenu zavisi od percepcije onoga ko je definiše, zbog čega se međusobne optužbe o ugroženosti hibridnim pretnjama svode na nivo spoljnopolitičke retorike, koja je, kao što je pokazano, ipak praćena i postupnom implementacijom hibridnih pretnji i koncepta hibridnog ratovanja u strateške dokumente analiziranih država i organizacija.

\section{Identifikacija hibridnih pretnji u strateškim dokumentima Evropske unije}

Aktuelnost hibridnih pretnji na nivou EU, pre svega se ogleda $\mathrm{kroz}$ usvajanje niza dokumenata i implementaciju praksi i politika, usmerenih na suočavanje sa ovim problemom, čime se u poslednjih nekoliko godina progresivno razvija strateški okvir koji oblikuje bezbednosnu politiku EU u ovoj oblasti. Osim što je aspekt hibridnih pretnji zastupljen u opštoj, bezbednosnoj strategiji EU, značajne su i sve brojnije analize, izveštaji i okviri specifično posvećeni ovoj problematici, te će u radu biti fokus na analizi sledećih dokumenata: Globalna strategija EU za spoljnu i bezbednosnu politiku (2016), Zajednički okvir za suzbijanje hibridnih pretnji - odgovor EU (2016), Regulativa EU o jačanju otpornosti i povećanju sposobnosti za odgovor na hibridne pretnje (2018).

Globalna strategija Evropske unije za spoljnu

i bezbednosnu politiku (2016)

Globalna strategija Evropske unije za spoljnu i bezbednosnu politiku, pod nazivom Zajednička vizija, udruženo delovanje: jača Evropa, predstavlja dokument koji daje osnovne pravce spoljnopolitičkog delovanja EU u

${ }^{39}$ Richard Youngs, Is 'hybrid geopolitics' the next EU foreign policy doctrine?, LSE European Politics and Policy (EUROPP) Blog, 19 June 2017, Internet, http:/ /eprints.lse.ac.uk/ 82158/1/blogs.lse.ac.uk-Is\%20hybrid \%20geopolitics \% 20the \%20next \%20EU\% 20foreign \%20policy\%20doctrine.pdf, 11/09/2020.

${ }^{40}$ Ibid., p. 1. 
globalizovanom i dinamičnom svetu koji se neprestano menja. ${ }^{41}$ Usvajanje Globalne strategije zapravo je predstavljalo priliku za EU da, u uslovima višedimenzionalne krize, usaglasi izgradnju spoljne, bezbednosne i odbrambene politike Unije za drugu i treću deceniju XXI veka. ${ }^{42} \mathrm{U}$ akademskoj literaturi Globalna strategija EU tretira se kao „realpolitika sa evropskim karakteristikama“, oličena u većem insistiranju na tvrdoj moći, nego na demokratizaciji, ${ }^{43}$ drugim rečima, kao „realističniji“ vodič za spoljnu i bezbednosnu politiku EU u bliskoj budućnosti, ${ }^{44}$ koji širi strateško razmišljanje EU i odražava njeno nastojanje da poboljša svoje sposobnosti u rešavanju bezbednosnih problema koje SAD ne smatraju prioritetnim..$^{45} \mathrm{U}$ Strategiji se naglašava multidimenzionalnost izazova po bezbednost Unije, što se ogleda $u$,hibridnim pretnjama, terorizmu, ekonomskoj nestabilnosti, klimatskim promenama i energetskoj nesigurnosti, koji ugrožavaju stanovništvo i teritoriju EU“ “ ${ }^{46}$ Kako hibridne pretnje ne poznaju granice, ističe se nužnost čvršcih institucionalnih veza između spoljnog delovanja i unutrašnjeg prostora slobode, bezbednosti i pravde, kao i bolja povezanost odbrambene politike sa politikama koje pokrivaju unutrašnje tržište, industriju i svemir. ${ }^{47}$ Takođe, suzbijanje hibridnih i sajber pretnji, iziskuje i produbljivanje partnerstva sa NATO, koordiniranim razvojem odbrambenih sposobnosti, paralelnim i sinhronizovanim vežbama i međusobno podržavajućim akcijama za izgradnju zajedničkih kapaciteta. ${ }^{48}$

Globalna strategija EU definisala je upravljanje odnosima sa Rusijom kao „,ključni strateški izazov za evropsku bezbednost", ocenjujući da su kršenje međunarodnog prava od strane Rusije i destabilizacija Ukrajine, povrh

41 "A Global Strategy for the European Union's Foreign and Security Policy - Shared Vision, Common Action: A Stronger Europe", European Commision, Brussels, June 2016, Internet, https://eeas.europa.eu/sites/eeas/files/eugs_review_web_0.pdf, 12/09/2020.

${ }^{42}$ Duško Lopandić, Evropska unija i Srbija: novo vreme i novo okruženje, Evropski pokret u Srbiji, Beograd, 2017.

${ }^{43}$ Sven Biscop, "The EU global strategy: Realpolitik with European characteristics", in: Jan Woischnik (ed.), Might and Right in World Politics, Konrad-Adenauer-Stiftung, Rio de Janeiro, 2016, pp. 91-100.

${ }^{44}$ Karen E. Smith, E, "A European Union global strategy for a changing world?", International Politics, vol. 54, no. 4, 2017, pp. 503-518.

${ }^{45}$ Michael E. Smith, "Transatlantic security relations since the European security strategy: what role for the EU in its pursuit of strategic autonomy?", Journal of European Integration, vol. 40, no. 5, 2018, pp. 605-620.

46 "A Global Strategy for the European Union's Foreign and Security Policy - Shared Vision, Common Action: A Stronger Europe", op. cit., p. 9.

${ }^{47}$ Ibid., p. 53.

${ }^{48}$ Ibid., p. 40. 
dugotrajnih konflikata u široj crnomorskoj oblasti, doveli u pitanje samu suštinu evropskog bezbednosnog poretka. ${ }^{49}$ Stoga se Globalnom strategijom ukazuje na važnost integrisanog pristupa, kako bi se interne aktivnosti povezale sa spoljnim delovanjem EU, i u tom kontekstu ističe se potreba za povećanjem fokusa EU na sajber bezbednost i unapređenje strateške komunikacije..$^{50}$ Time je Unija generalno osigurala koherentnost između svoje spoljne i unutrašnje politike i povećala saradnju sa NATO, ali je pristup EU po tim pitanjima i dalje omeđen institucionalnom $i$ finansijskom fragmentacijom između država članica. ${ }^{51}$ Iako se očigledno, u Globalnoj strategiji EU, hibridne pretnje spominju više fragmentarno, bez detaljne analize, njihovo samo uključivanje u krucijalni strateški dokument EU, otvorilo je prostor da se pitanju hibridnih pretnji i strategijama suprotstavljanja posveti veća pažnja u pojedinačnim, specifičnim dokumentima.

\section{Zajednički okvir za suzbijanje hibridnih pretnji}

- odgovor Evropske unije (2016)

Zajedničkim okvirom za suzbijanje hibridnih pretnji teži se unapređenju sveobuhvatnog pristupa suzbijanju hibridnih pretnji, zasnovanog na saradnji država članica, uspostavljanju sinergije među svim relevantnim instrumentima i podsticanju bliske saradnje sa ključnim akterima, pre svega NATO. ${ }^{52} \mathrm{U}$ dokumentu se navodi da, iako se definicije hibridnih pretnji razlikuju, te moraju biti fleksibilne kako bi se odgovorilo na njihovu promenljivu prirodu, konceptom se nastoji obuhvatiti „kombinacija prisilne i subverzivne aktivnosti, konvencionalnih i nekonvencionalnih metoda (tj. diplomatskih, vojnih, ekonomskih i tehnoloških), koje državni ili nedržavni akteri mogu upotrebljavati na koordinisan način kako bi postigli specifične ciljeve, bez službene objave rata" ${ }^{53}$ Naglasak je na iskorišćavanju slabosti protivnika i stvaranju nejasnoća kako bi se omeli procesi odlučivanja, te tako velike kampanje dezinformisanja javnosti, u kojima se koriste društvene

${ }^{49}$ Ibid., p. 33.

50 "Security and Defence: Significant Progress to Enhance Europe's Resilience against hybrid threats-more work ahead", July 2017, European Commission - Press release, Brussels, Internet, https://ec.europa.eu/commission/presscorner/detail/en/IP_17_ 2064, 30/09/2020, p. 9.

${ }^{51}$ Maria G. A. Viceré, The EUGS and Russian hybrid warfare: effective implementation but insufficient results, Foundation for European Progressive Studies, Brussels, March 2019, Internet, https://www.iai.it/en/pubblicazioni/eugs-and-russian-hybrid-warfareeffective-implementation-insufficient-results, 29/09/2020.

52 "Joint Framework on countering hybrid threats - a European Union response", European Commission, Brussels, April, 2016, Internet, https://eur-lex.europa.eu/ legal-content/EN/TXT/PDF/?uri=CELEX:52016JC0018\&from=EN, 29/09/2020.

${ }^{53}$ Ibid., p. 2. 
mreže za kontrolu političkog uticaja ili radikalizaciju, regrutovanje i usmeravanje aktera, mogu biti pokretači hibridnih pretnji. ${ }^{54}$

U Okviru se obrazlaže proces suprotstavljanja hibridnim pretnjama, počev od prepoznavanja njihove prirode, podizanja svesti, jačanja otpornosti, preko sprečavanja krize, odgovora na krizu do oporavka, pri čemu se u okviru svakog od navedenih odgovora predviđaju konkretne mere, $\mathrm{u}$ rasponu od poboljšanja razmene informacija, zaštite kritične infrastrukture, aktiviranja i delovanja tela i jedinica specifično formiranih za suprotstavljanje hibridnim pretnjama, do sajber bezbednosti, izgradnje otpornih društava i jačanja saradnje sa NATO ${ }^{55}$ Pomenute aktivnosti se nastavljaju na postojeće strategije i sektorske politike kojima se doprinosi postizanju veće bezbednosti, te se kao "strateški alati“ kojima se takođe može doprineti suzbijanju hibridnih pretnji, navode Evropska bezbednosna agenda, Globalna strategija EU za spoljnu i bezbednosnu politiku, Evropski akcioni plan odbrane, Strategija sajber bezbednosti EU, Strategija energetske bezbednosti i Strategija pomorske bezbednosti. ${ }^{56}$ Kroz ovaj okvir delovanja Evropska unija naglašava da, iako države članice imaju primarnu odgovornost, jer je većina nacionalnih slabosti specifična za pojedine države, usled opasnosti, nepredvidivosti i prekograničnog karaktera hibridnih pretnji, za efikasnije rezultate neophodno je usvajanje kompleksnih i sveobuhvatnih mera i aktivnosti, odnosno koordinisan odgovor na nivou EU. ${ }^{57}$

Regulativa EU o jačanju otpornosti i povećanju sposobnosti za odgovor na hibridne pretnje (2018)

Polazeći od toga da hibridne aktivnosti državnih i nedržavnih aktera i dalje predstavljaju ozbiljnu i akutnu pretnju za EU i države članice, svrha ovog dokumenta jeste izveštavanje o rezultatima rada na suzbijanju hibridnih pretnji, nastavak takve prakse, te utvrđivanje područja u kojima bi trebalo pojačati delovanje Unije. ${ }^{58}$ Posebno se naglašava potreba jačanja kapaciteta EU za otkrivanje i sprečavanje hibridnih pretnji u područjima kao što su: sajber bezbednost, strateška komunikacija i obaveštajne aktivnosti, kao i podizanje otpornosti na hemijske, biološke, radiološke i nuklearne pretnje. ${ }^{59}$

${ }^{54}$ Ibid.

${ }^{55}$ Ibid., p. 3.

${ }^{56}$ Ibid.

${ }^{57}$ Ionut, A. Cîrdei \& Lucian Ispas, "A possible answer of the European Union to Hybrid Threats", Scientific Bulletin, vol. 22, no. 2, 2017, pp. 71-78.

58 "Joint Communication on Increasing Resilience and Bolstering Capabilities to Address Hybrid Threats", European Commission, Brussels, June 2018, Internet, https:/ / eeas. europa.eu/sites/eeas/files/joint_communication_increasing_resilience_and_bolsterin g_capabilities_to_address_hybrid_threats.pdf, 30/09/2020.

${ }^{59}$ Ibid., p. 2. 
$\mathrm{Uz}$ predstavljene rezultate preduzetih aktivnosti $\mathrm{u}$ različitim segmentima: počev od napretka u suzbijanju dezinformisanja, gde je posebno istaknut štetan uticaj Rusije, pojačanih mera protiv hemijskih, bioloških, radioloških i nuklearnih pretnji, do jačanja otpornosti na neprijateljske obaveštajne aktivnosti i odvraćanja u oblasti sajber bezbednosti, istovremeno su projektovani i budući koraci u navedenim oblastima. ${ }^{60}$ Sastavni deo tih napora je i jačanje kapaciteta za odgovor na krize, gde je pružena potpora u vidu zajedničkih vežbi sa NATO savezom, s ciljem temeljnog ispitivanja kapaciteta EU za odgovor na hibridne krize velikih razmera. ${ }^{61}$ U Izveštaju o sprovođenju Regulative EU kao ključna dostignuća u ovoj oblasti izdvajaju se: progresivan razvoj čitavog korpusa alata, metoda i strategija za suprotstavljanje hibridnim pretnjama, usvajanje velikog broja zakonodavnih predloga koji podržavaju napore na nacionalnom i na nivou EU, usvajanje režima hemijskih i sajber sankcija kao mera odgovora, praktikovanje sveobuhvatnog pristupa, koji se zasniva na bliskoj saradnji i koordinaciji između EU institucija i država članica, kao i angažmanu čitavog društva-vlasti, civilnog društva, privatnog sektora, medija itd. ${ }^{62}$ Zaključuje se da se dalji izazovi sastoje u očuvanju i dodatnom jačanju povezanosti i integrisanosti navedenih politika i mera, kako bi se strategija suzbijanja hibridnih pretnji realizovala na efikasan i održiv način. ${ }^{63}$

\section{"Hibridni odgovor" na hibridnu pretnju - sveobuhvatni pristup EU suprotstavljanju hibridnim pretnjama}

Nužnost prilagođavanja promenjenim globalnim okolnostima (relativno slabljenje hegemonije SAD, uspon starih velikih sila poput Kine i Rusije, sve češće političke, ekonomske i bezbednosne krize unutar EU i u njenom okruženju), jeste ono što je podstaklo Uniju na izgradnju i potvrdu sopstvenog identiteta na međunarodnoj sceni, odnosno jačanje političke i vojne komponente kako bi mogla da deluje nezavisno od američke zaštite i dominacije. Potreba za "osmostaljivanjem“ i intenzivnijim bavljenjem sopstvenom bezbednošću, dovela je i do adresiranja hibridnih pretnji kao važnog bezbednosnog problema, odnosno njihovog uključivanja u strateške dokumente i preduzimanja strategija i mera za suzbijanje istih, što

\footnotetext{
${ }^{60}$ Ibid., pp. 5-9.

${ }^{61}$ Ibid., p. 2.

62 "Report on the implementation of the 2016 Joint Framework on countering hybrid threats and the 2018 Joint Communication on increasing resilience and bolstering capabilities to address hybrid threats", European Commision, Brussels, May 2019, Internet, https:// www.statewatch.org/news/2019/jun/eu-com-hr-implementationreport-hybrid-threats-swd-2019-200.pdf, 01/10/2020, p. 25.

${ }^{63}$ Ibid.
} 
predstavlja deo jačanja bezbednosne politike EU. Posebno su procesi i događaji, kao što je ukrajinska kriza i njen geopolitički značaj u smislu uloge Rusije, označavanja tog događaja od strane "zapada“ kao hibridnog rata/hibridnih operacija, posledično narušenih ekonomskih i energetskih odnosa EU i Rusije, zajedno sa jačanjem tehnološke i informacione dimenzije savremenih konflikata, stvorili okolnosti u kojima je teško razlikovati stanje mira od stanja rata i koje su pogodne za klasifikovanje brojnih neprijateljskih akata kao hibridnih pretnji. Stoga, kompleksan i višedimenzionalan karakter hibridnih pretnji, nameće potrebu da i adekvatan odgovor na iste mora biti sveobuhvatan, odnosno, zahteva aktivno delovanje u svim segmentima društva, baš kao što hibridne pretnje pogađaju političku, sajber, medijsku, ekonomsku, tehničko-tehnološku i druge dimenzije. Kako je EU vremenom naglašavala evoluciju i destabilizujući karakter hibridnih pretnji po svoju bezbednost, tako je sveobuhvatni pristup, očigledno postao suštinski princip delovanja koji uokviruje strategije, politike i aktivnosti u oblasti suzbijanja hibridnih pretnji. Tako je insistiranje Unije na unutrašnjoj (među institucijama i državama članicama) i spoljašnjoj saradnji i integraciji, te usklađivanju širokog spektra instrumenata i aktivnosti, rezultiralo i zvaničnim usvajanjem sveobuhvatnog pristupa u decembru 2013. godine. Osim što se ističe neophodnost angažovanja svih aktera i raspoloživih instrumenata: vojnih snaga, diplomatskih i političkih mera, ekonomskih instrumenata, tehnologije i humanitarne pomoći, dodaje se da je važno shvatiti da promene bezbednosnog okruženja uslovljene hibridnim pretnjama mogu dugoročno uticati na stabilnost međunarodnog poretka i menjanje globalnih centara moći. ${ }^{64} \mathrm{~S}$ obzirom na to da se $\mathrm{u}$ brojnim dokumentima i istraživačkim analizama ističe da su hibridne pretnje, kao teško predvidljive, fluidne i nestrukturisane, jedan od najvećih izazova sa kojima se EU suočava, spektar aktivnih i pasivnih, preventivnih i reaktivnih mera za smanjenje ranjivosti i rizika, uključuje: razvoj okvira za prepoznavanje i mehanizama za sprečavanje, ograničenje efekata i suzbijanje ovih pretnji, pripremu stanovništva za razumevanje pretnji i načina njihove manifestacije, stvaranje kulture otpornosti, promovisanje partnerstva između vlasti i stanovništva, jačanje institucija i razvoj posebnih centara, usvajanje zakonodavnih mera prilagođenih novim izazovima, podsticanje razmene informacija i unutrašnje i međunarodne saradnje..$^{65}$ Dakle, ono što je najvažnije, jeste kombinacija spoljnih i unutrašnjih bezbednosnih politika i instrumenata. U operativnom smislu, to znači da bi svaki zajednički odgovor na hibridne pretnje širom EU, trebalo da se zasniva na sinergiji i jasnoj podeli odgovornosti između tri grupe aktivnosti/instrumenata: 1) instrumenata i

${ }^{64}$ Patryk Pawlak, "Understanding hybrid threats", op. cit., p. 2.

${ }^{65}$ Ionut A. Cîrdei, “The Hybrid Warfare in the $21^{\text {st }}$ century: An Old Concept with a New Face", Paper presented at the International Conference Knowledge-based organization, vol. 23, no. 1, 2017, pp. 74-78. 
aktivnosti država članica; 2) instrumenata EU za unutrašnju bezbednost; 3) spoljnih bezbednosnih instrumenata EU (uključujući operacije i misije Zajedničke bezbednosne i odbrambene politke - ZBOP) i NATO aktivnosti. ${ }^{66}$ Dakle, uspešno suprotstavljanje hibridnim pretnjama podrazumeva i širenje opsega ZBOP u pravcu praćenja i ranog upozoravanja, prikupljanja informacija za suzbijanje propagande, podrške strateškoj komunikaciji, osiguranja kritične infrastrukture i podrške državama članicama u suzbijanju prisilnih i subverzivnih dejstava. ${ }^{67}$ Naravno, kako hibridne pretnje zahtevaju hibridne odgovore i kapacitete, to znači i angažovanje civilnih aktera, a posebno čvršću civilno-vojnu saradnju koja je nužna za osiguranje delotvornog odgovora EU na destabilizujuće pretnje protiv država članica, država u susedstvu EU i šireg međunarodnog poretka. ${ }^{68}$

Iz ranije navedenog, očigledno je da kontramere sada pokrivaju gotovo sve oblasti - od informaciono-digitalne sfere, kritične infrastrukture, preko sajber bezbednosti, bezbednosti granica, do ekonomskog, energetskog i pomorskog sektora, odnosno počivaju na mobilisanju društvenih, ekonomskih, diplomatskih, vojnih, medijskih, informacionih i drugih kapaciteta i na jačanju otpornosti u svim segmentima. U tom smislu, sveobuhvatni pristup EU suprotstavljanju hibridnim pretnjama dalje će se razmatrati kroz razvijenu institucionalnu strukturu, podržanu konkretnim aktivnostima, među kojima će biti fokus na sankcijama i strateškoj komunikaciji, odnosno suprotstavljanju dezinformisanju, kao i kroz saradnju sa NATO savezom kojom Unija, na neki način, zaokružuje svoj sistem odbrane od hibridnih pretnji.

Institucionalni okvir i ključne aktivnosti EU

u suprotstavljanju hibridnim pretnjama

Institucionalizacija suzbijanja hibridnih pretnji pojavljuje se kao strategija za suočavanje sa "poznatim nepoznanicama“, ali istovremeno ukazuje na

${ }^{66}$ Jan Joel Andersson \& Thierry Tardy, Hybrid: what's in a name? Brief Issue, No. 32/2015, The European Union Institute for Security Studies (EUISS), Paris, October 2015, Internet, https://www.iss.europa.eu/sites/default/files/EUISSFiles/Brief_32_Hybrid _warfare.pdf, 1/10/2020, p. 2.

${ }^{67}$ Margriet Drent, Lennart Landman \& Dick Zandee, A New Strategy - Implications for CSDP, Clingendael Report, Netherlands Institute for International Relations, Hague, June 2016, Internet, https:/ / www.clingendael.org/sites/default/files/pdfs/Clingendael \% 20Report \% 20-\% 20A \% 20New \% 20Strategy \% 20-\%20Implications \% 20for \% 20CSDP\%20-\%20June\%202016_0.pdf, 01/10/2020.

${ }^{68}$ Francesco Giumelli, Eugenio Cusumano \& Matteo Besana, "From Strategic Communication to Sanctions: The European Union's Approach to Hybrid Threats", in: Eugenio Cusumano \& Marian Corbe (eds), A civil-military response to hybrid threats, Palgrave Macmillan, London and New York, 2018, pp. 145-167. 
problematičnu i nejasnu razliku između politike i rata, odnosno na potencijalnu političku agendu skrivenu iza borbe protiv hibridnih pretnji. ${ }^{69}$ U poslednjih nekoliko godina uspostavljen je veći broj institucija i agencija na nivou EU za potrebe suočavanja sa hibridnim pretnjama, ali se kao najznačajnije mogu izdvojiti Evropski centar izvrsnosti za suzbijanje hibridnih pretnji (European Centre of Excellence for Countering Hybrid Threats), Združena hibridna jedinica (Hybrid Fusion Cell) i Radna grupa za strateške komunikacije za istočno susedstvo (East StratCom Task Force).

Evropski centar izvrsnosti za suzbijanje hibridnih pretnji predstavlja „multinacionalnu mrežu praktičara i stručnjaka, koji rade na jačanju sposobnosti država članica za suzbijanje hibridnih pretnji, razmenom najboljih praksi, testiranjem novih ideja i pristupa i sprovođenjem obuka i vežbi“ ${ }^{70} \mathrm{U}$ središtu pažnje Centra, jeste istraživanje načina sprovođenja "hibridnih strategija“, te podsticanje razvoja novih koncepata i tehnologija u privatnom sektoru i industriji radi pružanja podrške državama članicama u jačanju otpornosti. Takvi napori su usmereni i na usklađivanje nacionalnih i evropskih politika, doktrina i koncepata, kao i osiguravanju da se pri donošenju odluka uzimaju u obzir složenosti i nejasnoće povezane sa hibridnim pretnjama. ${ }^{71}$ Centar obuhvata 22 države članice EU i saveznike iz NATO, te ima važnu ulogu u jačanju saradnje između EU i NATO, kao jedinstven forum preko kojeg se obezbeđuju strateško komuniciranje i održavanje zajedničkih obuka i vežbi dve organizacije. ${ }^{72}$

Za efikasno suprotstavljanje hibridnim pretnjama, neophodno je pravovremeno identifikovanje bilo kakvih promena $\mathrm{u}$ bezbednosnom okruženju, povezanih sa hibridnim aktivnostima državnih i/ili nedržavnih aktera, zbog čega je važno unapređivanje razmene informacija i obaveštajnih podataka između sektora unutar Unije i između EU, njenih država članica i partnera. ${ }^{73} \mathrm{U}$ tom smislu, Združena hibridna jedinica, osnovana 2016. unutar Obaveštajnog i situacionog centra, takođe je jedna od značajnih institucija, koja na osnovu tajnih i informacija iz otvorenih izvora o hibridnim pretnjama, obezbeđuje strateške analize donosiocima odluka na nivou

${ }^{69}$ Maria Mälksoo, "Countering hybrid warfare as ontological security management: the emerging practices of the EU and NATO", European security, vol. 27, no. 3, 2018, pp. 374-392.

70 "Report on the implementation of the 2016 Joint Framework on countering hybrid threats and the 2018 Joint Communication on increasing resilience and bolstering capabilities to address hybrid threats", op. cit., p. 28.

71 "Joint Framework on countering hybrid threats - a European Union response", op. cit., p. 5.

72 Ibid., p. 28.

73 "Joint Framework on countering hybrid threats - a European Union response", op. cit., p. 4. 
Unije. ${ }^{74}$ Dakle, zadatak ove službe je da nadgleda i analizira spoljne aspekte hibridnih pretnji koje utiču na EU i njeno susedstvo, uključujući pružanje doprinosa proceni bezbednosnog rizika sprovedenoj na nivou EU. ${ }^{75}$ Ove aktivnosti se realizuju u saradnji sa Obaveštajnom direkcijom Vojnog štaba EU (EUMSINT) i kroz različite mreže kontakata na nivou EU i na nacionalnom nivou. Nacionalne kontakt tačke zapravo čine različite vladine službe, okupljene kako bi se izgradila otpornost na hibridne pretnje i kreirale inicijative za suprotstavljanje istim. ${ }^{76}$

U ovom kontekstu može se zaključiti da je strateško komuniciranje $u$ vidu borbe protiv dezinformisanja jedna od suštinskih aktivnosti EU u oblasti suprotstavljanja hibridnim pretnjama, kojoj se pridaje veliki značaj kroz naglašavanje negativnog uticaja dezinformacija na demokratske procese u državama članicama i slobodno odlučivanje građana, zbog čega je važno podizanje javne svesti i bezbednosne kulture stanovništva. ${ }^{77}$ Otkrivanje i suzbijanje dezinformacija i propagandnih aktivnosti, kao ključnih komponenti hibridnih operacija, odvijaju se kroz mehanizme strateške komunikacije koji obuhvataju niz relevantnih područja, poput veće transparentnosti, pouzdanosti internet platformi, verodostojnosti izbornih procesa, podsticanja obrazovanja i medijske pismenosti, kao i kvalitetnog novinarstva. ${ }^{78}$ Drugim rečima, suština mehanizma strateške komunikacije zasniva sa na efikasnom komuniciranju i koordiniranoj razmeni informacija, kao i na uspostavljanju zajedničkog operativnog protokola i sprovođenju periodičnih vežbi za poboljšanje strateških kapaciteta za donošenje odluka, kao odgovor na složene hibridne pretnje. ${ }^{79}$ Spoljne politike za stratešku komunikaciju EU je razvila i u okviru Globalne strategije ZSBP, usklađujući ih vremenom sa unutrašnjim inicijativama i ističući da će nastaviti da unapređuje svoju stratešku komunikaciju, investiranjem u javnu diplomatiju širom različitih oblasti, kako bi se spoljna politika EU povezala sa građanima i na bolji način predstavila državama partnerima..$^{80}$

74 "Joint Communication on Increasing Resilience and Bolstering Capabilities to Address Hybrid Threats", op. cit., p. 2.

75 "Joint Framework on countering hybrid threats - a European Union response", op. cit., p. 4.

76 "Report on the implementation of the 2016 Joint Framework on countering hybrid threats and the 2018 Joint Communication on increasing resilience and bolstering capabilities to address hybrid threats", op. cit., p. 3.

77 "Joint Communication on Increasing Resilience and Bolstering Capabilities to Address Hybrid Threats", op. cit., p. 3.

${ }^{78}$ Ibid.

${ }^{79}$ Ionuț A. Cîrdei \& Lucian Ispas, “A possible answer of the European Union to Hybrid Threats", op. cit., p. 74.

80 "A Global Strategy for the European Union's Foreign and Security Policy - Shared

40 Vision, Common Action: A Stronger Europe", op. cit., p. 23. 
U institucionalnom smislu, u ovoj oblasti ključnu ulogu ima Radna grupa East StratCom, koja se fokusira na tri segmenta: 1) efektivna komunikacija i promocija politika EU u zemljama istočnog partnerstva; 2) podrška slobodi medija i jačanje nezavisnih medija; 3) jačanje sposobnosti EU za predviđanje i podizanje svesti o dezinformacijskim aktivnostima od strane spoljnih aktera. ${ }^{81} \mathrm{~S}$ obzirom na to da je glavni fokus na uticajima i aktivnostima Rusije, ova radna grupa je aktivno angažovana na unapređenju javne diplomatije Unije objavljivanjem analitičkih članaka, pouzdanih studija i izveštaja o tzv. ruskom dezinformisanju. ${ }^{82}$ Zajedno sa kasnije formiranim Radnim grupama za južno susedstvo i Zapadni Balkan, Radna grupa za istočno susedstvo je sastavni deo Odeljenja za strateške komunikacije Evropske spoljnopolitičke službe (Strategic Communications Division of the European External Action Service), koja ima vodeću ulogu u suzbijanju dezinformacija i suočavanju sa hibridnim pretnjama. ${ }^{83}$ Kao što je predviđeno Akcionim planom protiv dezinformisanja, Odeljenje za strateške komunikacije, usmereno je na otkrivanje, analiziranje i izlaganje dezinformacija, podizanje svesti o negativnom uticaju istih, mobilizaciju privatnog sektora i poboljšanje društvene otpornosti, a u bliskoj saradnji sa Komisijom, Evropskim parlamentom i državama članicama. ${ }^{84}$

Pored strateške komunikacije, kao tzv. instrumenta meke moći, drugu vrstu političkog odgovora na hibridne pretnje predstavljaju sankcije, kao tradicionalni instrument. ${ }^{85}$ Sankcije se uvode npr. nedržavnim akterima koji preduzimaju prisline i subverzivne aktivnosti, koje ne dostižu prag ratovanja, ali i akterima/državama koje su konfliktno nastrojene, ti. teže narušavanju mira (npr. slučajevi Sirije, Libije, Egipta, Tunisa). ${ }^{86}$ Sankcije prema Rusiji su najupečatljiviji primer primene ove politike restriktivnih mera. Naime, odgovor EU na aktivnosti Rusije u ukrajinskoj krizi, prešao je iz logike uključivanja u delimično isključenje, pri čemu su se neke evropske vlade usredsredile i na klasične oblike diplomatije za uspostavljanje kompromisa

81 "Report on the implementation of the 2016 Joint Framework on countering hybrid threats and the 2018 Joint Communication on increasing resilience and bolstering capabilities to address hybrid threats", op. cit., p. 26.

${ }^{82}$ Maria G. A. Viceré, The EUGS and Russian hybrid warfare: effective implementation but insufficient results, op. cit., p. 4.

83 "Report on the implementation of the 2016 Joint Framework on countering hybrid threats and the 2018 Joint Communication on increasing resilience and bolstering capabilities to address hybrid threats", op. cit., p. 26.

${ }^{84}$ Ibid.

${ }^{85}$ Francesco Giumelli, Eugenio Cusumano \& Matteo Besana, "From Strategic Communication to Sanctions: The European Union's Approach to Hybrid Threats", op. cit., p. 146.

${ }^{86}$ Ibid., p. 160. 
sa Rusijom, van okvira institucionalnih instrumenata EU ${ }^{87}$ Međutim, rezultat navedene odluke su bili i veliki finansijski gubici i rast nezadovoljstva privrednika i građana u pojedinim članicama EU, koji su stoga pojačali pritisak na politički vrh u svojim državama da se sankcije ublaže ili čak ukinu, u cilju zaštite sopstvenih finansijskih i političkih institucija od negativnog uticaja krize. ${ }^{88} \mathrm{U}$ Globalnoj strategiji EU čak se navodi da restriktivne mere, udružene sa diplomatijom, čine ključno sredstvo za postizanje mirovnih promena. Dodaje se da tzv. pametne sankcije mogu imati ključnu ulogu u odvraćanju, sprečavanju konflikata i njihovom rešavanju, te se u skladu sa međunarodnim pravom i pravom EU, pažljivo odmeravaju i posmatraju kao znak podrške legitimnoj ekonomiji i izbegavanju nanošenja štete lokalnim društvima. ${ }^{89}$ Ova vrsta mehanizma obuhvata širi spektar sankcija, između ostalog i sankcije u oblasti sajber i hemijskih pretnji, kao i sankcije na proliferaciju OMU, gde je EU uvela i režim sankcija na trgovinu sredstvima dvostruke namene, tj. robom, softverima $i$ tehnologijom koji se mogu koristiti i u vojne i civilne svrhe, te mogu biti iskorišćena i od strane nedržavnih aktera za sprovođenje nasilnih aktivnosti. ${ }^{90} \mathrm{~S}$ obzirom na veliko unutrašnje tržište i ograničene vojne kapacitete EU, sankcije i restriktivne mere su i do sada imale bitnu ulogu u spoljnopolitičkom delovanju EU, te će verovatno ostati značajni mehanizmi u odgovoru EU na hibridne pretnje i naporima da poveća otpornost na svojim granicama, u susedstvu, ali i šire. ${ }^{91}$

\section{EU-NATO saradnja u suprotstavljanju hibridnim pretnjama}

Na osnovu prethodne analize politika i praksi EU u suprotstavljanju hibridnim pretnjama, lako je uočiti da važno mesto u celokupnom spektru zauzima saradnja i partnerstvo sa NATO savezom. Porast hibridnih taktika i strategija, te umnožavanje nejasnoća i izazova koje donose, vodili su progresivnom zbližavanju dve organizacije na temelju hibridnih pretnji,

${ }^{87}$ Richard Youngs, Is 'hybrid geopolitics' the next EU foreign policy doctrine?, op. cit. p. 2.

${ }^{88}$ Miroslav Terzić, Miroslav Talijan, Aleksandar Dumić i Dragan Stevanović, „Hibridno ratovanje i globalne tendencije Evropske unije“, u: Zbornik radova sa 12. međunarodnog savetovanja Rizik i bezbednosni inženjering, Visoka tehnička škola strukovnih studija, Novi Sad, 2017, str. 47-52.

89 "A Global Strategy for the European Union's Foreign and Security Policy - Shared Vision, Common Action: A Stronger Europe", op. cit., p. 37.

${ }^{90}$ Francesco Giumelli, Eugenio Cusumano \& Matteo Besana, "From Strategic Communication to Sanctions: The European Union's Approach to Hybrid Threats", op. cit., p. 161.

${ }^{91}$ Mark Galeotti, Hybrid war or gibridnaya voina? Getting Russia's non-linear military challenge right, Mayak Intelligence, Prague, 2016, p. 35. 
percipiranih kao očigledno zajedničkog i ozbiljnog bezbednosnog problema. Zajednički nastup i čvršća saradnja EU i NATO u suprotstavljanju hibridnim pretnjma i nizu drugih bezbednosnih pitanja, kao što su pomorska bezbednost, sajber bezbednost, izgradnja otpornosti i odbrambenih kapaciteta, ozvaničeni su potpisivanjem dve zajedničke deklaracije (Warsaw Joint Declaration 2016, Brussels Joint Declaration 2018). ${ }^{92}$ Zajedničkom deklaracijom sa samita u Varšavi, iz 2016. godine, pomeren je fokus sa političkog dijaloga i jačanja institucionalnih akcija ka povećanju sposobnosti za suprotstavljanje hibridnim pretnjama, kroz "zajedničku analizu, prevenciju i rano otkrivanje, pravovremenu razmenu informacija, razmenu obaveštajnih podataka, kao i stratešku komunikaciju i efikasan odgovor “. ${ }^{93}$ Istovremeno je i Globalnom strategijom EU najavljeno produbljivanje partnerstva sa NATO, kroz „,koordiniran razvoj odbrambene sposobnosti, paralelne i sinhronizovane vežbe i međusobnu izgradnju kapaciteta, kako bi se borili protiv hibridnih i visokotehnoloških pretnji i promovisali pomorsku bezbednost ${ }^{\prime \prime}{ }^{94}$ Isticanje nužnosti saradnje u svetlu zajedničkih izazova i međusobno isprepletanih bezbednosnih politika vodilo je kontinuiranom unapređenju, ali i širenju opsega zajedničkih praksi u suzbijanju hibridnih pretnji, te se u Zajedničkoj deklaraciji iz 2018. godine, kao konkretni rezultati navode: „pojačana spremnost za krize, pravovremena razmena informacija, borba protiv dezinformisanja, izgradnja otpornosti članova i partnera, testiranje sposobnosti i aktivnosti paralelnim i koordiniranim vežbama“ ${ }^{95}$ Naravno, nije teško primetiti, da je između ostalog, „rusko ugrožavanje evroatlantske bezbednosti“ dalo impuls navedenom zbližavanju, isticanjem da su „ruske agresivne i provokativne aktivnosti i pokazana spremnost za postizanje političkih ciljeva pretnjom i upotrebom sile, izvor regionalne nestabilnosti i ugrožavanja dugogodišnjeg cilja - slobodne i bezbedne Evrope ${ }^{\prime \prime}{ }^{96}$ Geopolitička i istorijska pozadina ovakvog konstruisanja neprijatelja će verovatno i dalje izazivati podozrivost prema često isticanoj ugroženosti zapadnih saveznika hibridnim pretnjama,

${ }^{92}$ Daniel Fiott \& Roderick Parkes, Protecting Europe - The EU's response to hybrid threats, op. cit., p. 6.

93 "Joint declaration by the President of the European Council, the President of the European Commission and the NATO Secretary General", Internet, https:// www.consilium.europa.eu/media/21481/nato-eu-declaration-8-july-en-final.pdf, 03/10/2020, p. 1.

94 "A Global Strategy for the European Union's Foreign and Security Policy - Shared Vision, Common Action: A Stronger Europe", op. cit., p. 42.

95 "Joint Declaration on EU-NATO Cooperation by the President of the European Council, the President of the European Commission, and the NATO Secretary General", Internet, https:/ /www.nato.int/cps/en/natohq/official_texts_156626.htm, 03/10/2020, p. 1.

96 "Warsaw Summit Declaration”, op. cit., para. 5. 
kako sa „istoka“, tako i sa „juga", ali su praktične konsekvence takvog procesa neminovne, što se upravo ogleda u stalnom unapređivaju saradnje EU i NATO u ovoj oblasti, kroz zajedničke vežbe, simulacije, inicijative itd.

U pogledu potencijala buduće saradnje prisutni su predlozi da bi ista trebalo da se zasniva i na usklađivanju ciljeva Zajedničke spoljne i bezbednosne politike EU i bezbednosnih ciljeva NATO, kao i na rešavanju postojećih nedostataka i problema dupliranja aktivnosti. ${ }^{97}$ Stvaranje vojne šengenske zone, razvijanje PESCO projekta u pravcu boljeg usklađivanja sa odbrambenim ciljevima EU i NATO i potpuno uključivanje država članica EU u Program za strategijski vazdušni transport (SAC), takođe su neki od načina, na koje se saradnja EU i NATO može dodatno ojačati, kako bi se zajedničkom borbom protiv hibridnih pretnji unapredilo bezbednosno okruženje. ${ }^{98}$

\section{Zaključak}

Napredovanje procesa globalizacije, tehničko-tehnološkog razvoja i time uslovljenih promena $u$ društvu, međunarodnim odnosima i bezbednosnim procesima, predstavlja širi okvir političko-ekonomskih kretanja i geopolitičkih uslovljenosti, $u$ kojem je neophodno sagledavati nove pretnje i izazove, odnosno promene u praktikovanju i promišljanju bezbednosti. Dinamičnost i složenost ovih procesa praćena je novim, još uvek nejasnim obrisima savremenih sukoba i načinima njihovog vođenja, te se kao najprikladniji opis njihovog maglovitog i kompleksnog karaktera, $\mathrm{u}$ modernoj literaturi i globalnom političkom i bezbednosnom diskursu, javljaju pojmovi kao što su "hibridne pretnje“ i „hibridni ratovi“. Prateći ove promene, Evropska unija je kroz razvijen sistem politika, strategija, struktura i konkretnih mera oblikovala svoju bezbednosnu politiku, tako da je u značajnoj meri usmerena ka suzbijanju hibridnih pretnji. Dakle, ako se stave po strani dileme o hibridnim pretnjama, kao politički kontroverznom fenomenu ili pak samo pojmu pogodnom za široke interpretacije i upotrebe, odnosno opravdavanje brojnih aktivnosti u cilju zaštite sopstvenih interesa i širenja uticaja, na osnovu prethodne analize, nesumnjivo je da apostrofiranje njihove prisutnosti i negativnih efekata po evropsku bezbednost proizvodi posledice na praktičnom planu, dakle u bezbednosnoj politici EU i evropskoj bezbednosnoj arhitekturi. Naime, počev od Evropske bezbednosne agende, gde se hibridne pretnje spominju tek kao verovatne u budućnosti, preko očiglednog porasta usmerenosti na iste, kroz Globalnu strategiju EU za spoljnu i bezbednosnu politiku, Zajednički okvir za suprotstavljanje hibridnim pretnjama, te

${ }^{97}$ Hope DeMint, EU-NATO Relations: A Future of Cooperation or Conflict?, Internet, http://eucenter.scrippscollege.edu/wp-content/uploads/files/2018/03/EU-NATORelations-Hope-DeMint.pdf, 03/10/2020, p. 10.

$44 \quad{ }^{98}$ Ibid., p. 13. 
Regulativu EU o jačanju otpornosti i povećanju sposobnosti za odgovor na hibridne pretnje, ali i mnoge druge izveštaje i analize, ono što se može uočiti kao zajedničko ovim ključnim dokumentima EU jeste isticanje Rusije kao glavnog izvora hibridnih pretnji po bezbednost Unije. Takva percepcija je uslovila i izgradnju razvijenog sistema konkretnih mera i aktivnosti, kao i institucija za suprotstavljanje hibridnim pretnjama, zasnovanih na principu "hibridnog odgovora na hibridnu pretnju“, odnosno jačanju kapaciteta i sposobnosti u svim oblastima, u cilju što efikasnije odbrane, uključujući i blisku saradnju sa NATO savezom, kroz zajedničke deklaracije, inicijative i vežbe. Međutim, bez obzira na čitav spektar političkih i institucionalnih rešenja EU, izgrađenih na temelju ugroženosti od hibridnih pretnji, kao i na postojeća teorijska određenja i tumačenja istih koje pruža Unija, pitanje supstantivnog karaktera hibridnih pretnji, njihove jasne klasifikacije i operacionalizacije i dalje ostaje pod velom konfuzija. Iako to može biti razumljivo s obzirom na to da je reč o bezbednosnoj problematici koja je u povoju i još uvek u domenu nedovoljno istraženog, pred Evropskom unijom ostaje izazov jasne konceptualizacije hibridnih pretnji, jer usmeravanje i vođenje bezbednosne politike u cilju suzbijanja hibridnih pretnji ne samo da oblikuje političke odnose globalnih aktera, već zahteva i temeljno razmatranje načina organizovanja odbrane, uloge savremene tehnologije $u$ današnjim sukobima i uopšte poimanje rata i mira, usled sve zamagljenije linije između njih. Istovremeno, EU je i dalje u procesu pozicioniranja u novom globalnom poretku i u meri u kojoj će uspeti da "nađe svoje mesto", shodno proklamovanom nastojanju da deluje odlučnije i ojača svoju „tvrdu moć“, u toj meri će, između ostalog, zavisiti i njena sposobnost da osigura sopstvenu bezbednost i suprotstavi se hibridnim pretnjama.

\section{Bibliografija}

“A Global Strategy for the European Union's Foreign and Security Policy Shared Vision, Common Action: A Stronger Europe", European Commision, Brussels, June 2016, Internet, https://eeas.europa.eu/ sites/eeas/files/eugs_review_web_0.pdf, 12/09/2020.

Aleksandrić, Radomir, „Istorijsko-komparativna analiza nastanka i eksploatacije doktrine hibridnog ratovanja u oružanim snagama Ruske Federacije", u: Nebojša Nikolić (ur.), Hibridno ratovanje - dilema koncepta savremenih sukoba, Institut za strategijska istraživanja, Beograd, 2018, str. 110-131.

Andersson, Jan Joel \& Tardy, Thierry, Hybrid: what's in a name? Brief Issue, No. 32/2015, The European Union Institute for Security Studies (EUISS), Paris, October 2015, Internet,https://www.iss.europa.eu/sites/ default/files/EUISSFiles/Brief_32_Hybrid_warfare.pdf, 1/10/2020. 
Bērziņš, Jānis, "Not 'Hybrid' but New Generation Warfare", in: Glen E. Howard \& Matthew Czekaj (eds), Russia's military strategy and doctrine, The Jamestown foundation,Washington D.C., 2019, pp. 157-184.

Biscop, Sven, "The EU global strategy: Realpolitik with European characteristics", in: Jan Woischnik (ed.), Might and Right in World Politics, Konrad-Adenauer-Stiftung, Rio de Janeiro, 2016, pp. 91-100.

"Brussels Summit Declaration", North Atlantic Council, Brussels, 11-12 July 2018, Internet, https:/ / www.nato.int/nato_static_fl2014/assets/pdf/ pdf_2018_07/20180713_180711-summit-declaration-eng.pdf, 07/09/2020.

Cîrdei, Ionut A. \& Ispas, Lucian, "A possible answer of the European Union to Hybrid Threats", Scientific Bulletin, vol. 22, no. 2, 2017, pp. 71-78.

Cîrdei, Ionut A., "The Hybrid Warfare in the $21^{\text {st }}$ century: An Old Concept with a New Face", Paper presented at the International Conference Knowledge-based organization, vol. 23, no. 1, 2017, pp. 74-78.

DeMint, Hope, EU-NATO Relations: A Future of Cooperation or Conflict?, Internet, http://eucenter.scrippscollege.edu/wp-content/uploads/ files/2018/03/EU-NATO-Relations-Hope-DeMint.pdf, 03/10/2020.

Drent, Margriet, Landman, Lennart \& Zandee, Dick, A New Strategy Implications for CSDP, Clingendael Report, Netherlands Institute for International Relations, Hague, June 2016, Internet, https:// www.clingendael.org/sites/default/files/pdfs/Clingendael\%20Report $\% 20-\% 20 \mathrm{~A} \% 20 \mathrm{New} \%$ 20Strategy \% 20-\% 20Implications $\% 20$ for $\%$ 20CSDP\%20-\%20June\%202016_0.pdf, 01/10/2020.

Facon, Isabelle, Russia's national security strategy and military doctrine and there implications for the EU, In-depth analysis, European Union, DirectorateGeneral for External Policies, Brussels, January 2017, Internet, https://www.europarl.europa.eu/RegData/etudes/IDAN/2017/57801 6/EXPO_IDA\%282017\%29578016_EN.pdf, 11/09/2020.

Fiott, Daniel \& Parkes, Roderick, Protecting Europe - The EU's response to hybrid threats, Chaillot Paper, No.151, European Union Institute for Security Studies (EUISS), Paris, April 2019, Internet, https:// www.researchgate.net/profile/Daniel_Fiott/publication/333104934_Pr otecting_Europe_the_EU's_response_to_hybrid_threats/links/5cdbcef9 299bf14d95988c67/Protecting-Europe-the-EUs-response-to-hybridthreats.pdf, 03/10/2020.

Galeotti, Mark, Hybrid war or gibridnaya voina? Getting Russia's non-linear military challenge right, Mayak Intelligence, Prague, 2016.

Giumelli, Francesco, Cusumano, Eugenio \& Besana, Matteo, "From Strategic Communication to Sanctions: The European Union's Approach to Hybrid Threats", in: Eugenio Cusumano \& Marian Corbe (eds), A civil- 
military response to hybrid threats, Palgrave Macmillan, London and New York, 2018, pp. 145-167.

Hoffman, Frank G., Conflict in the 21st Century -The Rise of Hybrid Wars, Potomac Institute for Policy Studies, Arlington, Virginia, 2007.

"Joint Communication on Increasing Resilience and Bolstering Capabilities to Address Hybrid Threats", June 2018, European Commission, Brussels, Internet, https:/ / eeas.europa.eu/sites/eeas/files/joint_communication _increasing_resilience_and_bolstering_capabilities_to_address_hybrid_t hreats.pdf, 30/09/2020.

"Joint declaration by the President of the European Council, the President of the European Commission and the NATO Secretary General", Internet, https://www.consilium.europa.eu/media/21481/nato-eudeclaration-8-july-en-final.pdf, 03/10/2020.

"Joint Declaration on EU-NATO Cooperation by the President of the European Council, the President of the European Commission, and the NATO Secretary General", Internet, https:/ / www.nato.int/cps/en/ natohq/official_texts_156626.htm, 03/10/2020.

"Joint Framework on countering hybrid threats - a European Union response", European Commission, Brussels, April, 2016, Internet, https://eur-lex.europa.eu/legal-content/EN/TXT/PDF/?uri=CELEX: 52016JC0018\&from=EN, 29/09/2020.

Lopandić, Duško, Evropska unija i Srbija: novo vreme i novo okruženje, Evropski pokret u Srbiji, Beograd, 2017.

Mälksoo, Maria, "Countering hybrid warfare as ontological security management: the emerging practices of the EU and NATO", European security, vol. 27, no. 3, 2018, pp. 374-392.

"Military Doctrine of the Russian Federation", Ministry of Defense, Moscow, 2014, Internet, https://www.offiziere.ch/wp-content/uploads-001/ 2015/08/Russia-s-2014-Military-Doctrine.pdf, 07/09/2020.

Milošević, Davor, „Percepcija savremenih oružanih sukoba kao indikatora hibridnog koncepta rata, modeli prevencije i suprotstavljanja hibridnim pretnjama", Vojno delo, vol. 70, br. 5, 2018, str. 272-293.

Missiroli, Antonio, From Hybrid Warfare to 'Cybrid' Campaigns: The New Normal?, Center for Security Studies, Zürich, September 2019, Internet, https://css.ethz.ch/en/services/digital-library/articles/article.html/ a59d89dd-1179-453b-ab02-ade9097cf646, 11/09/2020.

Mölling, Christian, "From Hybrid Threats to Hybrid Security Policy", Ethics and Armed Forces, vol. 2, no. 2, 2015, pp. 17-19.

Newson, Robert A., Counter-Unconventional Warfare Is the Way of the Future. How Can We Get There?, Small Wars Journal, 23 October 2014, Internet, https://smallwarsjournal.com/blog/counter-unconventional-warfareis-the-way-of-the-future-how-can-we-get-there, 04/09/2020. 
North Atlantic Treaty Organization, NATO's response to hybrid threats, August 2019, Internet, https:/ /www.nato.int/cps/en/natohq/topics_156338. htm, 07/09/2020.

Pawlak, Patryk, Understanding hybrid threats, Briefing, European Parliamentary Research Service, Brussels, June 2015, Internet, https://www.europarl.europa.eu/RegData/etudes/ATAG/2015/5643 55/EPRS_ATA(2015)564355_EN.pdf, 11/09/2020.

Pejić, Igor „Ruske vojne hibridne operacije u Ukrajini: prilagođavanje strategije i taktike savremenoj strukturi rata", Medunarodni problemi, vol. 71, br. 4, 2019, str. 423-446.

"Quadrennial Defense Review", U.S. Department of Defense, Washington D.C., March 2010, Internet, https://archive.defense.gov/qdr/QDR\% 20as\%20of\%2029JAN10\%201600.pdf, 04/09/2020.

"Report on the implementation of the 2016 Joint Framework on countering hybrid threats and the 2018 Joint Communication on increasing resilience and bolstering capabilities to address hybrid threats", May 2019, European Commision, Brussels, Internet, https:/ / www.statewatch.org/ news/2019/jun/eu-com-hr-implementation-report-hybrid-threats-swd2019-200.pdf, 01/10/2020.

"Security and Defence: Significant Progress to Enhance Europe's Resilience against hybrid threats - more work ahead", July 2017, European Commission - Press release, Brussels, Internet, https://ec.europa.eu/ commission/presscorner/detail/en/IP_17_2064, 30/09/2020.

Smith, Karen E., "A European Union global strategy for a changing world?", International Politics, vol. 54, no. 4, 2017, pp. 503-518.

Smith, Michael E., "Transatlantic security relations since the European security strategy: what role for the EU in its pursuit of strategic autonomy?" , Journal of European Integration, vol. 40, no. 5, 2018, pp. 605-620.

Stojković, Dejan, „Hibridne pretnje bezbednosti Republike Srbije“, Vojno delo, vol. 69, br. 6, 2017, str. 277-292.

Terzić, Miroslav, Talijan, Miroslav, Dumić, Aleksandar iStevanović, Dragan, „Hibridno ratovanje i globalne tendencije Evropske unije“, u: Zbornik radova sa 12. međunarodnog savetovanja Rizik $i$ bezbednosni inženjering, Visoka tehnička škola strukovnih studija, Novi Sad, 2017, str. 47-52.

Terzić, Miroslav R., Miladinović, Mića D. i Coković, Sabahudin, „Hibridno ratovanje - konceptualna adaptacija“, Vojno delo, vol. 69, no. 5, 2017, str. 348-357.

"The National Military Strategy of the USA", Department of Defense, Washington D.C., June 2015, Internet, https://www.jcs.mil/Portals /36/Documents/Publications/2015_National_Military_Strategy.pdf, 04/09/2020. 
U.S. Department of Defense, Military Must Be Ready to Confront Hybrid Threats, September 2019,Internet,https:/ / www.defense.gov/Explore/ Features/story/Article/1952023/military-must-be-ready-to-confronthybrid-threats-intelligence-official-says/source/GovDelivery/, 07/10/2020.

Viceré, Maria G. A., The EUGS and Russian hybrid warfare: effective implementation but insufficient results, Foundation for European Progressive Studies, Brussels, March 2019, Internet, https:/ /www.iai.it/en/ pubblicazioni/eugs-and-russian-hybrid-warfare-effective-implementationinsufficient-results, 29/09/2020.

Владимиров, Александр, Гибридные войны в Общей теории войны, Военный университет МО РФ, Москва, 2015.

Vračar, Milinko, „Razmatranje adekvatnog teorijsko-epistemološkog pristupa u istraživanju fenomena hibridnog ratovanja", Vojno delo, vol. 69, br. 7, str. 292-307.

Vračar, Milinko S. i Tikhova, Vladlena V., „Diskurzivni pristup fenomenu hibridnog ratovanja", Vojno delo, vol. 70, br. 3, 2018, str. 317-342.

Vuković, Nebojša, „,Prilog pojmovnom određenju sintagme hibridni rat" ${ }^{\prime \prime}$ u: Nebojša Nikolić (ur.), Hibridno ratovanje - dilema koncepta savremenih sukoba, Institut za strategijska istraživanja, Beograd, 2018, str. 11-27.

"Wales Summit Declaration", North Atlantic Council, Wales, 5 September 2014, Internet, https://www.europarl.europa.eu/meetdocs/2014_2019/ documents/sede/dv/sede240914walessummit_/sede240914walessum mit_en.pdf, 07/09/2020.

"Warsaw Summit Declaration", North Atlantic Council, Warsaw, 8-9 July 2016, Internet, https://www.nato.int/cps/en/natohq/official_texts _133169.htm, 07/09/2020.

Youngs, Richard, Is 'hybrid geopolitics' the next EU foreign policy doctrine? LSE European Politics and Policy (EUROPP) Blog, 19 June 2017, Internet, http:/ / eprints.lse.ac.uk/82158/1/blogs.lse.ac.uk-Is $\% 20$ hybrid $\% 20$ geopolitics\%20the \%20next\%20EU\%20foreign\%20policy\%20doctrine.pdf, $11 / 09 / 2020$. 


\title{
COUNTERING HYBRID THREATS IN THE EUROPEAN UNION SECURITY POLICY
}

\begin{abstract}
The aim of this paper is to present the thematisation of hybrid threats in the security policy of the European Union and the way in which the Union counters these threats on the practical-political level. Based on a qualitative analysis of the content of strategic documents, as a methodological approach and analysis of the political and institutional framework in this field, it is ascertained that the EU is significantly oriented to hybrid threats in its security policy. However, the legitimate conduct of such a policy requires more coherence and precision in the explanation and operationalisation of hybrid threats, given their vague and complex nature. In other words, it is concluded that the gradual transition to a multipolar world order, associated with the simultaneous strengthening of the technological dimension of modern conflicts and the Union's coping with a set of crises, new uncertainties and reconsideration of its own "identity" and role on the global geopolitical scene can be understood as a context that generated a "picture of complexity and hybridity" and a European perception of security threats as hybrid, as well.
\end{abstract}

Keywords: European Union, hybrid threats, hybrid war, security policy, contemporary conflicts, security environment. 